\title{
In Vitro Mass Multiplication and Assessment of Genetic Stability of In Vitro Raised Artemisia absinthium L. Plants Using ISSR and SSAP Molecular Markers
}

\author{
B. Kour, G. Kour, S. Kaul, and M. K. Dhar \\ Plant Genomics Laboratory, School of Biotechnology, University of Jammu, Jammu 180006, India \\ Correspondence should be addressed to B. Kour; balbirbalio2@yahoo.co.in
}

Received 28 May 2014; Revised 28 July 2014; Accepted 28 July 2014; Published 13 August 2014

Academic Editor: Qingyi Yu

Copyright @ 2014 B. Kour et al. This is an open access article distributed under the Creative Commons Attribution License, which permits unrestricted use, distribution, and reproduction in any medium, provided the original work is properly cited.

The present investigations were made attempting to develop a rapid, reliable, and reproducible in vitro regeneration protocol for Artemisia absinthium L., a medicinal plant of Kashmir Himalayas. Out of several auxin-cytokinin combinations tested, Murashige and Skoog's (MS) medium supplemented with $0.5 \mathrm{mgL}^{-1}$ 2,4-dichlorophenoxyacetic acid $(2,4-\mathrm{D})$ and $0.5 \mathrm{mgL}^{-1} \mathrm{kinetin}(\mathrm{Kn})$ was found to be the best for the callus induction. On the other hand, $4.5 \mathrm{mgL}^{-1}$ 6-benzylaminopurine (BAP) and $0.5 \mathrm{mgL}^{-1} 1-\alpha$ naphthaleneacetic acid (NAA) in the medium resulted in maximum shoot induction from the callus. Similarly, BAP and NAA at a concentration of $1.5 \mathrm{mgL}^{-1}$ and $0.5 \mathrm{mgL}^{-1}$, respectively, proved to be the best for the multiple shoot induction from nodal explants. Numerous shoots were obtained from nodal explants after third subculture. In vitro rooting was maximum on medium containing indole-3-butyric acid (IBA) at $0.5 \mathrm{mgL}^{-1}$. The genetic stability of the in vitro raised plants of Artemisia absinthium was assessed using the intersimple sequence repeat (ISSR) and sequence-specific amplification polymorphism (SSAP) molecular markers. Both markers were able to detect the somaclonal variations in the callus regenerated plants, while no variation was detected in the plants regenerated from the nodal explants. SSAP has been found to be more useful in detection of variability as compared to ISSR molecular marker. The results of present study concluded that the direct regeneration protocol will be useful for the production of true to type plants of this medicinally important plant. This will go a long way in reducing the pressure on the natural populations for the secondary metabolite production, especially for extraction of essential oils.

\section{Introduction}

Artemisia is a large genus based on $>500$ species, distributed primarily in temperate and subtropical regions of Asia, Europe, and North America. Central Asia is known to be its center of diversification, while the Mediterranean region and North West America are two derived speciation areas [1]. Artemisia plants are mostly used for medicinal purposes, although some of these have been put to other uses like food, forage, ornamentals, or soil stabilizers in disturbed habitats. Some taxa are known to be toxic or allergenic while some others are invasive weeds, which can adversely affect crop yield [2].

Artemisia absinthium L., commonly known as wormwood, is a perennial herb. This plant is medicinally very important and has been used in traditional ways because of its antihelminthic, insecticidal, antiseptic, and antibacterial properties [3, 4]. In addition, the oil of $A$. absinthium has been found to repel the flies and fleas and mosquitoes and has been used to kill house flies [5]. Artemisinin, an important antimalarial drug, has also been reported to be present in $A$. absinthium [6].

In vitro propagation is a powerful tool for germplasm conservation and mass multiplication. This technique has been used for regeneration in many medicinal and aromatic plants, including several species of Artemisia. In vitro culturing of $A$. absinthium has been attempted by some workers [7-9]. However, genetic fidelity of the regenerated plants has not been evaluated. Many factors, like concentration and type of growth regulators, time of culture, and media composition, induce genetic and epigenetic variability in the regenerated plants [10]. Although cytological and biochemical analyses have been used to detect these variations, they suffer from many drawbacks. The problems associated with 
these markers can be overcome by the use of molecular markers. Different types of molecular markers have been used to examine the genetic variability as well as to assess the genetic fidelity of the tissue culture raised plants.

In A. absinthium, the production of true to type plants is very critical in production of uniform planting material and in commercial production of secondary metabolites, particularly artemisinin and essential oils. This is particularly important since field grown plants are vulnerable to biotic and abiotic stresses [11]. Besides, it has been reported that the concentration of artemisinin varies in plants growing in different geographical areas [8]. Although plant tissue culture is an efficient and reproducible technique for micropropagation, determining the genetic fidelity of these plants through molecular tools assumes great significance. The present study was aimed at developing an efficient protocol for in vitro regeneration using different explants and assessing genetic fidelity of micropropagated plants using DNA based markers.

\section{Material and Methods}

2.1. Plant Material. A. absinthium plants were collected from Baramulla, Kashmir (Jammu and Kashmir State, India), and transplanted in pots in the School of Biotechnology, University of Jammu, Jammu. Plant parts such as nodes, leaves, petioles, and roots were used as explants for raising in vitro cultures. Murashige and Skoog's [12] media containing growth regulators in various concentrations and supplemented with $3 \%$ sucrose and $0.8 \%$ agar were used. The explants were washed with mild detergent for 5-10 minutes, followed by five rinses in double distilled water. Thereafter, they were surfacesterilized with $70 \%$ ethanol for $30 \mathrm{sec}$, followed by treatment with $0.1 \%$ mercuric chloride for $5 \mathrm{~min}$, and were rinsed with sterile distilled water three times; then these explants were treated with $0.5 \%$ sodium hypochlorite for $3 \mathrm{~min}$ followed by 5 times rinses with sterilized distilled water. The explants of $\sim 1 \mathrm{~cm}$ were inoculated in different callus induction media.

2.2. Callus Induction. The cultures were maintained at an average temperature of $25^{\circ} \mathrm{C}$ with a photoperiod of $10 \mathrm{~h}$ light. The callus induction media consisted of MS media supplemented with $0.8 \%$ agar, $0.3 \%$ sucrose, and variable amounts of cytokinin and auxin, adjusted to $\mathrm{pH}$ 5.8. Different growth regulators used for callus induction were BAP, NAA, IAA, 2,4-D, and kinetin. The explants cultured on MS medium without growth regulators served as control. The callus was subcultured on the callus proliferation medium consisting of MS medium supplemented with different concentrations of BAP and IAA.

2.3. Induction of Shoots and Roots (Induction of Organogenesis). After the 6th subculture callus from callus proliferation medium was shifted to shoot induction media consisting of different concentrations of BAP and NAA. For direct regeneration of the shoots from the nodal explants, the latter were surface-sterilized and cultured on the MS medium supplemented with different concentrations of the BAP and NAA. These shoots were subsequently cultured on the shoot elongation medium for shoot development. The rooting of both direct and indirectly differentiated plants was achieved on MS medium supplemented with different concentrations of the IBA.

2.4. Design and Data Analysis. The experiments were set up in completely randomized design. For data analysis each treatment consisted of 10 replicates and for each replicate a minimum of three explants were used. Data was analyzed by applying the analysis of variance (ANOVA) to detect significant differences between means. Means differing significantly were compared using Duncan's multiple range test (DMRT) at $5 \%$ probability level.

2.5. Molecular Analysis. DNA was isolated from both in vitro and in vivo raised plants using the Plant DNA Isolation kit (Bangalore Genei, India). DNA thus isolated was dried and dissolved in TE buffer till further use. The PCR amplifications with ISSR primers were performed in a $25 \mu \mathrm{L}$ reaction volume containing $0.2 \mathrm{mM}$ dNTPs, $1 \mathrm{x}$ PCR buffer, $2.5 \mathrm{mM} \mathrm{MgCl}_{2}$, 1.2 U Taq DNA polymerase, and 5 pmol of primers. The thermal cycler conditions consisted of initial denaturation for $2 \mathrm{~min}$, followed by 35 cycles of denaturation for $30 \mathrm{sec}$ at $94^{\circ} \mathrm{C}$, annealing at $45^{\circ} \mathrm{C}$ for $30 \mathrm{sec}$, and extension for $2 \mathrm{~min}$ at $72^{\circ} \mathrm{C}$, with the final extension of 10 minutes. The amplified fragments were electrophoresed on a $2 \%$ agarose gel in $1 \mathrm{x}$ TAE and were visualized by ethidium bromide staining. Fifteen ISSR primers were used; however, final results were compiled for the best five primers (UBC808, UBC810, UBC816, UBC835, and UBC880). For SSAP analysis the protocol of Kour et al. [10] was followed. The DNA was restricted to the mean size of $0.5-1.0 \mathrm{~kb}$ using four base cutter enzymes, MseI in $100 \mu \mathrm{L}$ reaction volume. The DNA fragments were ligated with $\mathrm{MseI}$ adaptors and the samples were incubated at $20^{\circ} \mathrm{C}$ for $6 \mathrm{~h}$. The polymerase chain reaction was performed using primers against LTR region and RNase $\mathrm{H}$ motif. The thermal cycler conditions consisted of initial denaturation for $3 \mathrm{~min}$ at $94^{\circ} \mathrm{C}$ followed by 35 cycles of denaturation for $30 \mathrm{sec}$ at $94^{\circ} \mathrm{C}$, annealing at $45^{\circ} \mathrm{C}$ for $30 \mathrm{sec}$, extension for $2 \mathrm{~min}$ at $72^{\circ} \mathrm{C}$, and final extension for $7 \mathrm{~min}$. The PCR amplified fragments were electrophoresed on 10\% PAGE in $1 \mathrm{x}$ TBE buffer and were visualized by silver staining.

\section{Results and Discussion}

3.1. Callus Induction. The callus induction was achieved on MS media supplemented with different concentrations of BAP, NAA, IAA, 2,4-D, and kinetin either alone or in combination (Table 1). Explants inoculated in MS medium (without growth regulators), which served as control, remained green for one week and later turned brown (Figure 1(a)). Similar results have also been reported by Nin et al. [7] in Artemisia absinthium; however, they have observed death of explants on hormone-free medium within few days of culturing. As it is clear from Table 1 optimum callus induction was observed in the MS medium supplemented with $0.5 \mathrm{mgL}^{-1} 2,4-\mathrm{D}$ and $0.5 \mathrm{mgL}^{-1}$ kinetin (Figure 1(b)). The calli developed from leaves and petioles were creamy white in colour whereas 


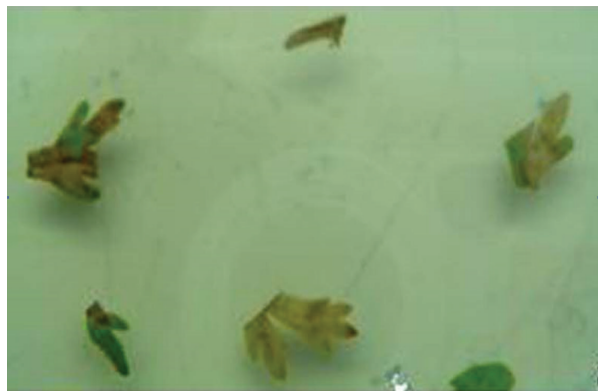

(a)

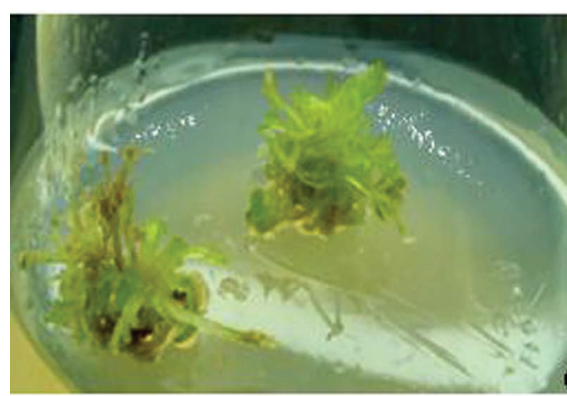

(c)

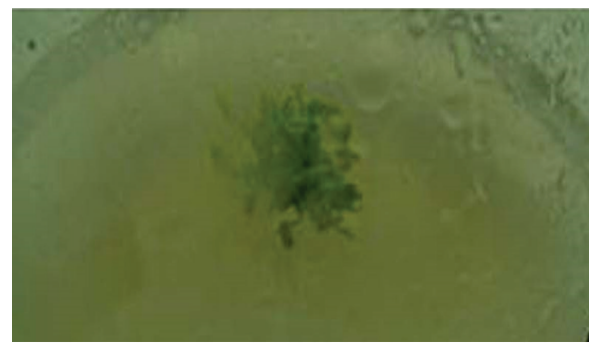

(e)

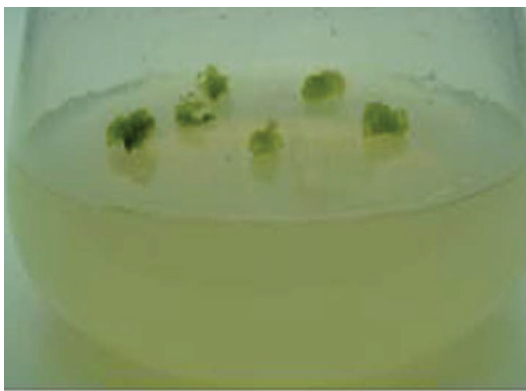

(b)

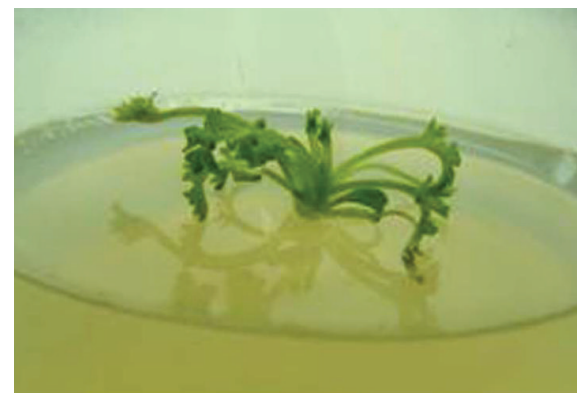

(d)

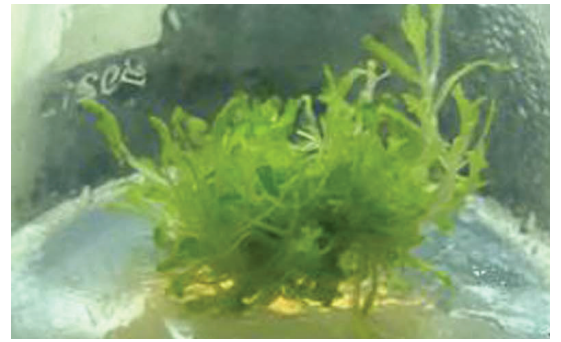

(f)

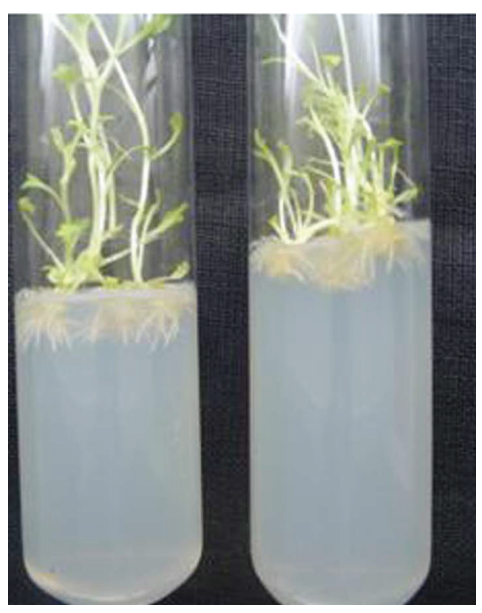

(g)

FIGURE 1: (a) Leaf explants on MS medium without plant growth regulator (PGR); (b) callus induction from leaf explants; (c) in vitro shoot regeneration from callus on MS medium; (d) shoot elongation; (e) in vitro shoot induction from nodal explant; (f) multiple shoot regeneration; (g) in vitro rooting on MS medium supplemented with IBA. 
TABLE 1: Callus induction in A. absinthium on MS medium supplemented with various plant growth regulators.

\begin{tabular}{|c|c|c|c|c|c|c|c|}
\hline S. number & $\begin{array}{c}2,4-\mathrm{D} \\
\left(\mathrm{mgL}^{-1}\right)\end{array}$ & $\begin{array}{c}\mathrm{BAP} \\
\left(\mathrm{mgL}^{-l}\right)\end{array}$ & $\begin{array}{c}\mathrm{IAA} \\
\left(\mathrm{mgL}^{-l}\right)\end{array}$ & $\begin{array}{c}\mathrm{KIN} \\
\left(\mathrm{mgL}^{-l}\right)\end{array}$ & $\begin{array}{c}\mathrm{NAA} \\
\left(\mathrm{mgL}^{-l}\right)\end{array}$ & $\begin{array}{l}\text { Days required for callus } \\
\text { induction }\end{array}$ & Colour of callus formed \\
\hline 1 & - & - & - & - & - & No response & - \\
\hline 2 & 0.5 & - & - & 0.5 & - & 8 & White \\
\hline 3 & 0.5 & - & - & 1.0 & - & 10 & White \\
\hline 4 & 1.0 & - & - & 0.5 & - & 15 & Creamy white \\
\hline 5 & 1.5 & - & - & 1.5 & - & No response & - \\
\hline 6 & - & 0.5 & 0.5 & - & - & 10 & Light green \\
\hline 7 & - & 1.0 & 0.5 & - & - & 12 & Light green \\
\hline 8 & - & 1.0 & 1.0 & - & - & 12 & Light green \\
\hline 9 & - & 0.5 & - & - & 0.5 & No response & - \\
\hline 10 & - & 1.0 & - & - & 0.5 & 15 & White \\
\hline 11 & - & 1.0 & - & - & 1.0 & No response & - \\
\hline 12 & - & 1.0 & 1.5 & - & - & 18 & Light green \\
\hline
\end{tabular}

TABLE 2: Callus proliferation in MS medium containing various plant growth regulators.

\begin{tabular}{|c|c|c|c|c|c|c|c|}
\hline S. number & $\begin{array}{c}2,4-\mathrm{D} \\
\left(\mathrm{mgL}^{-1}\right)\end{array}$ & $\begin{array}{c}\mathrm{BAP} \\
\left(\mathrm{mgL}^{-l}\right)\end{array}$ & $\begin{array}{c}\text { IAA } \\
\left(\mathrm{mgL}^{-l}\right)\end{array}$ & $\begin{array}{c}\mathrm{KIN} \\
\left(\mathrm{mgL}^{-l}\right)\end{array}$ & $\begin{array}{c}\mathrm{NAA} \\
\left(\mathrm{mgL}^{-l}\right)\end{array}$ & Rate of callus proliferation & Colour of the callus \\
\hline 1 & 0.5 & - & - & 0.5 & - & Very slow & White \\
\hline 2 & 0.5 & - & - & 1.0 & - & Slow & White \\
\hline 3 & 1.0 & - & - & 0.5 & - & Very slow & Creamy white \\
\hline 4 & - & 0.5 & 0.5 & - & - & Slow & Light green \\
\hline 5 & - & 1.0 & 0.5 & - & - & High & Light green \\
\hline 6 & - & 1.0 & 1.0 & - & - & Slow & Green \\
\hline 7 & - & 0.5 & - & - & 0.5 & Very slow & Creamy white \\
\hline 8 & - & 1.0 & - & - & 0.5 & Slow & Creamy white \\
\hline 9 & - & 1.0 & - & - & 1.0 & Slow & Light green \\
\hline 10 & - & 3.0 & 0.5 & - & - & Slow & Light green \\
\hline 11 & 2.5 & - & - & 0.5 & - & No proliferation & Brown \\
\hline 12 & 2.5 & - & - & - & - & No proliferation & White \\
\hline 13 & - & - & - & - & - & No proliferation & Brown \\
\hline
\end{tabular}

those on internodes were green. In addition to $2,4-\mathrm{D}$ and kinetin, callus induction was also observed on MS medium supplemented with BAP either alone or in combination with IAA. On this medium rate of callus induction was very slow and it took 8-15 days for achieving callus induction (Table 1). Callus thus formed was light green, soft and compact in nature. Similarly, on MS medium supplemented with kinetin alone as the hormone, the rate of callus formation was very slow. The callus thus formed was white and compact. Similar results have also been reported by $\mathrm{Zia}$ et al. [8]. BAP and NAA have been found to be most effective for callogenic response in A. absinthium (1996). Similar results have also been reported in Artemisia pallens using BAP and IAA [13].

3.2. Callus Proliferation and Shoot Induction. The callus thus obtained proliferated when subcultured on the callus proliferation medium. Maximum proliferation was observed on the MS medium supplemented with $1.0 \mathrm{mgL}^{-1} \mathrm{BAP}$ and $0.5 \mathrm{mgL}^{-1}$ IAA (Table 2). Subculturing was attempted after every 15 days and repeated 6 times till the callus turned green and nodular. Callus subcultured on BAP supplemented medium alone became nodular while, as on all other hormonal combinations friable, creamy white callus developed. Medium supplemented with kinetin resulted in the formation of compact and hard callus. Subsequently, the callus was subcultured on the shoot induction medium consisting of BAP and NAA (Table 3). MS medium supplemented with $4.5 \mathrm{mgL}^{-1} \mathrm{BAP}$ and $0.5 \mathrm{mgL}^{-1} \mathrm{NAA}$ was found to be ideal for shoot induction from the callus (Figure 1(c)). BAP has been reported as a beneficial hormone for the production of shoots in other members of Artemisia [14]. In A. judaica it has been observed that the shooting increased by about $80 \%$ after treatment with BAP alone or in combination with NAA [14]. MS media supplemented with only BAP at lower concentrations also led to the formation of shoots; however, number of shoots formed was less. These shootlets did not result in complete shoots when subcultured on the same medium or on shoot elongation medium; instead callus formation 
TABLE 3: Shoot induction from calli in various media.

\begin{tabular}{|c|c|c|c|c|c|c|}
\hline S. number & $\operatorname{BAP}\left(\mathrm{mgL}^{-1}\right)$ & $\mathrm{KIN}\left(\mathrm{mgL}^{-1}\right)$ & $\mathrm{NAA}\left(\mathrm{mgL}^{-1}\right)$ & IAA $\left(\mathrm{mgL}^{-1}\right)$ & Number of shoots & Length of shoots $(\mathrm{cm})$ \\
\hline 1 & - & 1.0 & 0.5 & - & No shoots & - \\
\hline 2 & - & 1.5 & 0.5 & - & No shoots & - \\
\hline 3 & - & 2.5 & 0.5 & - & No shoots & - \\
\hline 4 & - & 3.0 & - & 0.5 & No shoots & - \\
\hline 5 & 3.0 & - & 0.5 & - & $2.6 \pm 0.5^{\mathrm{c}}$ & $2.1 \pm 0.2^{\mathrm{b}}$ \\
\hline 6 & 3.5 & - & 0.5 & - & $3.5 \pm 0.5^{\mathrm{bc}}$ & $1.9 \pm 0.2^{\mathrm{ab}}$ \\
\hline 7 & 4.5 & - & 0.5 & - & $6.2 \pm 0.4^{\mathrm{a}}$ & $1.6 \pm 0.5^{\mathrm{c}}$ \\
\hline 8 & 5.0 & - & 0.5 & - & $1.8 \pm 0.4^{\mathrm{ab}}$ & $1.8 \pm 0.4^{\mathrm{a}}$ \\
\hline
\end{tabular}

Mean \pm SD of data based on 10 replicates per treatment. Means followed by the same letter are not significantly different using DMRT.

TABLE 4: Shoot induction from nodal explants cultured on various media.

\begin{tabular}{|c|c|c|c|c|c|c|}
\hline S. number & $\mathrm{BAP}\left(\mathrm{mgL}^{-1}\right)$ & $\mathrm{KIN}\left(\mathrm{mgL}^{-1}\right)$ & IAA $\left(\mathrm{mgL}^{-1}\right)$ & $\mathrm{NAA}\left(\mathrm{mgL}^{-1}\right)$ & Number of shoots & Length of shoots $(\mathrm{cm})$ \\
\hline 1 & 0.5 & - & - & 0.5 & - & - \\
\hline 2 & 1.0 & - & - & 0.5 & $1.8 \pm 0.5^{\mathrm{b}}$ & $1.3 \pm 0.3^{\mathrm{a}}$ \\
\hline 3 & 1.5 & - & - & 0.5 & $5.0 \pm 0.4^{\mathrm{b}}$ & $2.7 \pm 0.4^{\mathrm{b}}$ \\
\hline 4 & 2.0 & - & - & 0.5 & $1.6 \pm 0.5^{\mathrm{ab}}$ & $1.7 \pm 0.4^{\mathrm{a}}$ \\
\hline 5 & 2.5 & - & - & 0.5 & - & - \\
\hline 6 & - & 0.5 & 0.5 & - & - & - \\
\hline 7 & - & 1.0 & 0.5 & - & - & - \\
\hline 8 & - & 1.5 & - & 0.5 & - & - \\
\hline 9 & - & 2.0 & - & 0.5 & - & - \\
\hline 10 & - & 2.5 & - & 1.0 & - & - \\
\hline 11 & 0.5 & - & 0.5 & - & - & - \\
\hline 12 & 1.0 & - & 0.5 & - & - & - \\
\hline 13 & 1.5 & - & 0.5 & - & - & - \\
\hline 14 & 2.0 & - & 0.5 & - & - & - \\
\hline
\end{tabular}

Mean \pm SD of data based on 10 replicates per treatment. Means followed by the same letter are not significantly different using DMRT.

was observed. In the present study, higher concentration of BAP was observed to be beneficial for the shoot induction. This seems to be expected since the cytokinins are known to stimulate the cell division and axillary shoot formation [15]. BAP and NAA have been reported as excellent hormones for in vitro shoot regeneration in many plant species $[16,17]$.

For direct regeneration of shoots from the nodal explants, BAP at a concentration of $1.5 \mathrm{mgL}^{-1}$ and NAA at a concentration of $0.5 \mathrm{mgL}^{-1}$ were found to be critical (Table 4 ). Each nodal explant gave rise to multiple shoots (Figure 1(e)); the number of shoots increased with further subculturing (Figure 1(f)). The shoots thus formed were separated and subcultured on the shoot elongation medium (MS without growth regulators) for further development (Figure 1(d)). In Artemisia annua shoot proliferation has been achieved with the addition of BAP and NAA [11]. BAP has been rated as one of the most useful cytokinins for achieving the multiplication and micropropagation in plants.

The number of the shoots increased with further subculturing of explants on the MS medium supplemented with $1.5 \mathrm{mgL}^{-1} \mathrm{BAP}$ and $0.5 \mathrm{mgL}^{-1} \mathrm{NAA}$. Numerous shoots were observed after 40 days of subculturing (Figure 1(f)). The shoots thus formed showed the development and elongation on the MS medium without growth regulators (Figure 1(d)).
The shoots were subcultured on this medium for two weeks till they became healthier.

3.3. Rooting. Rooting was achieved from the well-developed shoots on half-strength MS medium supplemented with different concentrations of IBA (Table 5). Rooting was also observed from these shoots on MS medium without growth regulators, but the number of roots formed was less. MS medium supplemented with $0.5 \mathrm{mgL}^{-1}$ IBA was most effective for root induction (Figure $1(\mathrm{~g})$ ). The role of IBA as an effective root inducing auxin has also been seen in many other plant species as well $[18,19]$. With the increase in IBA concentration from $0.5 \mathrm{mgL}^{-1}$ to $2 \mathrm{mgL}^{-1}$, the rate of rooting got reduced and the shootlets showed callus formation instead of rooting.

3.4. Molecular Analysis. For the assessment of genetic fidelity of in vitro raised plants, ISSR and SSAP molecular markers were used (Table 6). ISSR primers resulted in $98 \%$ monomorphic bands in all the indirect in vitro raised plants, while plants regenerated from nodal explants were 100\% similar to their mother plant. The size of the amplification products ranged from $\sim 250 \mathrm{bp}$ to $\sim 3500 \mathrm{bp}$. The average number of bands amplified was 9 . Similar results have also been reported 
TABLE 5: Rooting in the regenerated shoots of A. absinthium on both half and full strength MS medium containing different concentrations of IBA.

\begin{tabular}{lcccccc}
\hline S. number & Source & Media & IBA $\left(\mathrm{mgL}^{-1}\right)$ & Number of roots per shoot & Number of days required for rooting & Length of roots $(\mathrm{cm})$ \\
\hline 1 & Shoots & MS & - & $1.0 \pm 0.5^{\mathrm{ef}}$ & 12 & $3.0 \pm 0.4^{\mathrm{a}}$ \\
2 & Shoots & MS & 0.5 & $2.8 \pm 0.4^{\mathrm{bcd}}$ & 8 & $2.6 \pm 0.8^{\mathrm{b}}$ \\
3 & Shoots & MS & 1.0 & $2.0 \pm 0.4^{\mathrm{bcd}}$ & 10 & $2.4 \pm 0.6^{\mathrm{b}}$ \\
4 & Shoots & MS & 1.5 & $1.3 \pm 0.5^{\mathrm{ef}}$ & 10 & $1.0 \pm 0.6^{\mathrm{e}}$ \\
5 & Shoots & $1 / 2 \mathrm{MS}$ & - & $1.8 \pm 0.5^{\mathrm{cde}}$ & 10 & $2.8 \pm 0.4^{\mathrm{a}}$ \\
6 & Shoots & $1 / 2 \mathrm{MS}$ & 0.5 & $5.8 \pm 0.3^{\mathrm{a}}$ & 12 & $1.8 \pm 0.4^{\mathrm{a}}$ \\
7 & Shoots & $1 / 2 \mathrm{MS}$ & 1.0 & $3.1 \pm 0.6^{\mathrm{b}}$ & $1.0 \pm 0.2^{\mathrm{cd}}$ \\
8 & Shoots & $1 / 2 \mathrm{MS}$ & 1.5 & $2.8 \pm 0.4^{\mathrm{bc}}$ & $1.4 \pm 0.4^{\mathrm{c}}$ \\
9 & Shoots & $1 / 2 \mathrm{MS}$ & 2.0 & $1.5 \pm 0.6^{\mathrm{ef}}$ & $1.2 \pm 0.3^{\text {cde }}$ \\
\hline
\end{tabular}

Mean \pm SD of data based on 10 replicates per treatment. Means followed by the same letter are not significantly different using DMRT.

TABLE 6: ISSR and SSAP primers used during the present investigation.

\begin{tabular}{|c|c|c|}
\hline S. number & Primer code & Sequence $\left(5^{\prime} \_3^{\prime}\right)$ \\
\hline 1 & UBC805 & (TA) $8 \mathrm{C}$ \\
\hline 2 & UBC807 & $(\mathrm{AG}) 8 \mathrm{~T}$ \\
\hline 3 & UBC808 & $(\mathrm{AG}) 8 \mathrm{C}$ \\
\hline 4 & UBC810 & (GA) $8 \mathrm{~T}$ \\
\hline 5 & UBC811 & (GA)8C \\
\hline 6 & UBC813 & $(\mathrm{CT}) 8 \mathrm{~T}$ \\
\hline 7 & UBC814 & $(\mathrm{CT}) 8 \mathrm{~A}$ \\
\hline 8 & UBC816 & $(\mathrm{CA}) 8 \mathrm{~T}$ \\
\hline 9 & UBC835 & (AG)8YC \\
\hline 10 & UBC841 & $(\mathrm{GA}) 8 \mathrm{YC}$ \\
\hline 11 & UBC842 & (GA)8YG \\
\hline 12 & UBC847 & $(\mathrm{CA}) 8 \mathrm{RC}$ \\
\hline 13 & UBC848 & $(\mathrm{CA}) 8 \mathrm{RG}$ \\
\hline 14 & UBC880 & $($ GGAGA)3 \\
\hline 15 & UBC881 & $($ GGGGT)3 \\
\hline 16 & MKD 4 & ACTGCCTTTTTACCATGG \\
\hline 17 & MKD5 & AACATATCATCAACATA \\
\hline 18 & MKD9 & CTAAGAGGCTACCACCAAAT \\
\hline 19 & MKD11 & ACACTTAGAGAACTTGGCA \\
\hline 20 & ASW8 & GATGGATCCTGAGTAAC \\
\hline 21 & ASW9 & GATGGATCCTGAGTAAAC \\
\hline 22 & ASW10 & GATGGATCCTGAGTAAACA \\
\hline
\end{tabular}

in almond [20], in banana [21], and in Gerbera jamesonii [22]. These results indicated that either in vitro raised plants were true to type or the ISSR marker was not able to detect somaclonal variation(s). Therefore, it became necessary to use more ISSR primers in order to reach a final conclusion. We tried more ISSR primers; however, the results were the same. Therefore, we took recourse to another marker system, namely, SSAP, for evaluating the status of in vitro raised plants. We used twelve primer pairs for the present investigation. The SSAP analysis revealed that the plants regenerated through the nodal explants were true to type, while callus derived plants were variable. With primer pair MKD9 and ASW9 a total of 22 bands were amplified in all the samples. In addition to these bands, three bands were observed in callus regenerated plants. Similarly, with primer pair MKD9 and ASW10, a total of 24 bands were observed while callus regenerated plants had four additional bands. Primer pairs MKD11 and ASW8 and MKD11 and ASW10 did not reveal any variation in the in vitro raised plants. From these results it can be inferred that callus regenerated plants exhibited somaclonal variations which could be detected by SSAP. Although somaclonal variations have been reported in several plants [10-24], the molecular basis of these changes is not clear. Various hypotheses have been put forward to explain this phenomenon. The best accepted hypothesis states that "in vitro culture represents breakdown of normal, default cellular controls resulting in a cascade of genetic and epigenetic instabilities and hence alterations in the gene expression and derivation of new phenotypes" $[25,26]$.

In conclusion the present investigation opens up a new route for in vitro clonal mass multiplication using nodal explants. In addition, the efficiency of SSAP as a molecular marker to detect the somaclonal variability has also been demonstrated. Moreover the results obtained in the present study might be useful in further research on genetic transformation and production of secondary metabolites in $A$. absinthium.

\section{Conflict of Interests}

The authors declare that there is no conflict of interests regarding the publication of this paper.

\section{Acknowledgment}

The authors thank the Department of Biotechnology, Government of India, for financial assistance.

\section{References}

[1] J. Valles and E. D. McArthur, "Artemisia systematics and phylogeny: cytogenetic and molecular in sights," in Proceedings of the Shrubland Ecosystem Genetics and Biodiversity, E. D. McArthur and D. J. Fairbanks, Eds., pp. 67-74, UT Ogden: US Department of Agriculture Forest Service, Rocky Mountain Research Station, Provo, Utah, USA, 2001. 
[2] M. Ashraf, M. Q. Hayat, S. Jabeen, N. Shaheen, M. A. Khan, and G. Yasmin, "Artemisia L. species recognized by the local community of northern areas of Pakistan as folk therapeutic plants," Journal of Medicinal Plants Research, vol. 4, no. 2, pp. 112-119, 2010.

[3] K. A. Tariq, M. Z. Chishti, F. Ahmad, and A. S. Shawl, "Anthelmintic activity of extracts of Artemisia absinthium against ovine nematodes," Veterinary Parasitology, vol. 160, no. 1-2, pp. 83-88, 2009.

[4] N. Kováts, F. Gölöncsér, A. Ács, and M. Refaey, "Quantification of the antibacterial properties of Artemisia absinthium, A. vulgaris, Chrysanthemum leucanthemum and Achillea millefolium using the Vibrio fischeri bacterial bioassay," Acta Botanica Hungarica, vol. 52, no. 1, pp. 137-144, 2010.

[5] C. Erichsen-Brown, Use of Plants for the Past 500 Years, Breezy Creek Press, Aurora, Canada, 1979.

[6] M. Zia and M. F. Chaudhary, "Effect of growth regulators and amino acids on artemisinin production in the callus of Artemisia absinthium," Pakistan Journal of Botany, vol. 39, no. 3, pp. 799-805, 2007.

[7] S. Nin, E. Morosi, S. Schiff, and A. Bennici, "Callus cultures of Artemisia absinthium L. initiation, growth optimization and organogenesis," Plant Cell, Tissue and Organ Culture, vol. 45, no. 1, pp. 67-72, 1996.

[8] M. Zia, R. Rehman, and M. F. Chaudhary, "Hormonal regulation for callogenesis and organgenesis of Artemisia absinthium L," African Journal of Biotechnology, vol. 6, no. 16, pp. 1874-1878, 2007.

[9] A. Mannan, T. N. Syed, M. A. Yameen et al., "Effect of growth regulators on in vitro germination of Artemisia absinthium," Scientific Research and Essays, vol. 7, pp. 1501-1507, 2012.

[10] G. Kour, B. Kour, S. Kaul, and M. K. Dhar, "Genetic and epigenetic instability of amplification-prone sequences of a novel $\mathrm{B}$ chromosome induced by tissue culture in Plantago lagopus L.," Plant Cell Reports, vol. 28, no. 12, pp. 1857-1867, 2009.

[11] S. Geng, Y. H. Chun, L. Gufeng et al., "Flowering of Artemisia annua L. test tube plantlets and Artemisinin production with shoot cluster induced from flower organs explants," Chinese Journal of Applied Environmental Biology, vol. 7, pp. 201-206, 2001.

[12] T. Murashige and F. Skoog, "A revised medium for rapid growth and bioassay with tobacco tissue culture," Plant Physiology, vol. 15, pp. 473-497, 1962.

[13] B. D. Benjamin, A. T. Sipahimalani, and M. R. Heble, "Tissue cultures of Artemisia pallens: organogenesis, terpenoid production," Plant Cell, Tissue and Organ Culture, vol. 21, no. 2, pp. 159$164,1990$.

[14] C. Z. Liu, S. J. Murch, M. EL-Demerdash, and P. K. Saxena, "Regeneration of the Egyptian medicinal plant Artemisia judaica L.," Plant Cell Reports, vol. 21, no. 6, pp. 525-530, 2003.

[15] L. Kyte and J. Kleyn, Plants from Test Tubes: An Introduction to Micropropagation, edited by J. H. Daquinta, Y. Gonzalez and C. G. Desjardins, 3rd edition, 1996.

[16] L. V. Be and P. C. Debergh, "Potential low-cost micropropagation of pineapple (Ananas comosus)," South African Journal of Botany, vol. 72, no. 2, pp. 191-194, 2006.

[17] A. R. Zuraida, A. H. N. Shahnadz, A. Harteeni, S. Roowi, C. M. Z. C. Radziah, and S. Sreeramanan, "A novel approach for rapid micropropagation of maspine pineapple (Ananas comosus L.) shoots using liquid shake culture system," African Journal of Biotechnology, vol. 10, no. 19, pp. 3859-3866, 2011.
[18] K. E. Danso, K. O. Ayeh, V. Oduro, S. Amiteye, and H. M. Amoatey, "Effect of 6-benzylaminopurine and naphthalene acetic acid on in vitro production of MD2 pineapple planting materials," World Applied Science Journal, vol. 3, pp. 614-619, 2008.

[19] M. T. Sultan, M. H. Khan, M. L. Hakim, A. N. K. Mamun, M. A. Morshed, and M. R. Islam, "In vitro plant regeneration from male flowers of banana," International Journal of Biosciences, vol. 1, pp. 1-11, 2011.

[20] M. Martins, D. Sarmento, and M. M. Oliveira, "Genetic stability of micropropagated almond plantlets, as assessed by RAPD and ISSR markers," Plant Cell Reports, vol. 23, no. 7, pp. 492-496, 2004.

[21] P. Joshi and V. Dhawan, "Assessment of genetic fidelity of micropropagated Swertia chirayita plantlets by ISSR marker assay," Biologia Plantarum, vol. 51, no. 1, pp. 22-26, 2007.

[22] R. Bhatia, K. P. Singh, T. R. Sharma, and T. Jhang, "Evaluation of the genetic fidelity of in vitro-propagated gerbera (Gerbera jamesonii Bolus) using DNA-based markers," Plant Cell, Tissue and Organ Culture, vol. 104, no. 1, pp. 131-135, 2011.

[23] M. Chandrika and V. R. Rai, "ISSR marker based analysis of micropropagated plantlets of Nothapodytes foetida," Biologia Plantarum, vol. 54, no. 3, pp. 561-565, 2010.

[24] B. C. Campbell, S. LeMare, G. Piperidis, and I. D. Godwin, "IRAP, a retrotransposon-based marker system for the detection of somaclonal variation in barley," Molecular Breeding, vol. 27, no. 2, pp. 193-206, 2011.

[25] R. L. Phillips, S. M. Kaeppler, and P. Olhoft, "Genetic instability of plant tissue cultures: breakdown of normal controls," Proceedings of the National Academy of Sciences of the United States of America, vol. 91, no. 12, pp. 5222-5226, 1994.

[26] S. M. Kaeppler, H. F. Kaeppler, and Y. Rhee, "Epigenetic aspects of somaclonal variation in plants," Plant Molecular Biology, vol. 43, no. 2-3, pp. 179-188, 2000. 

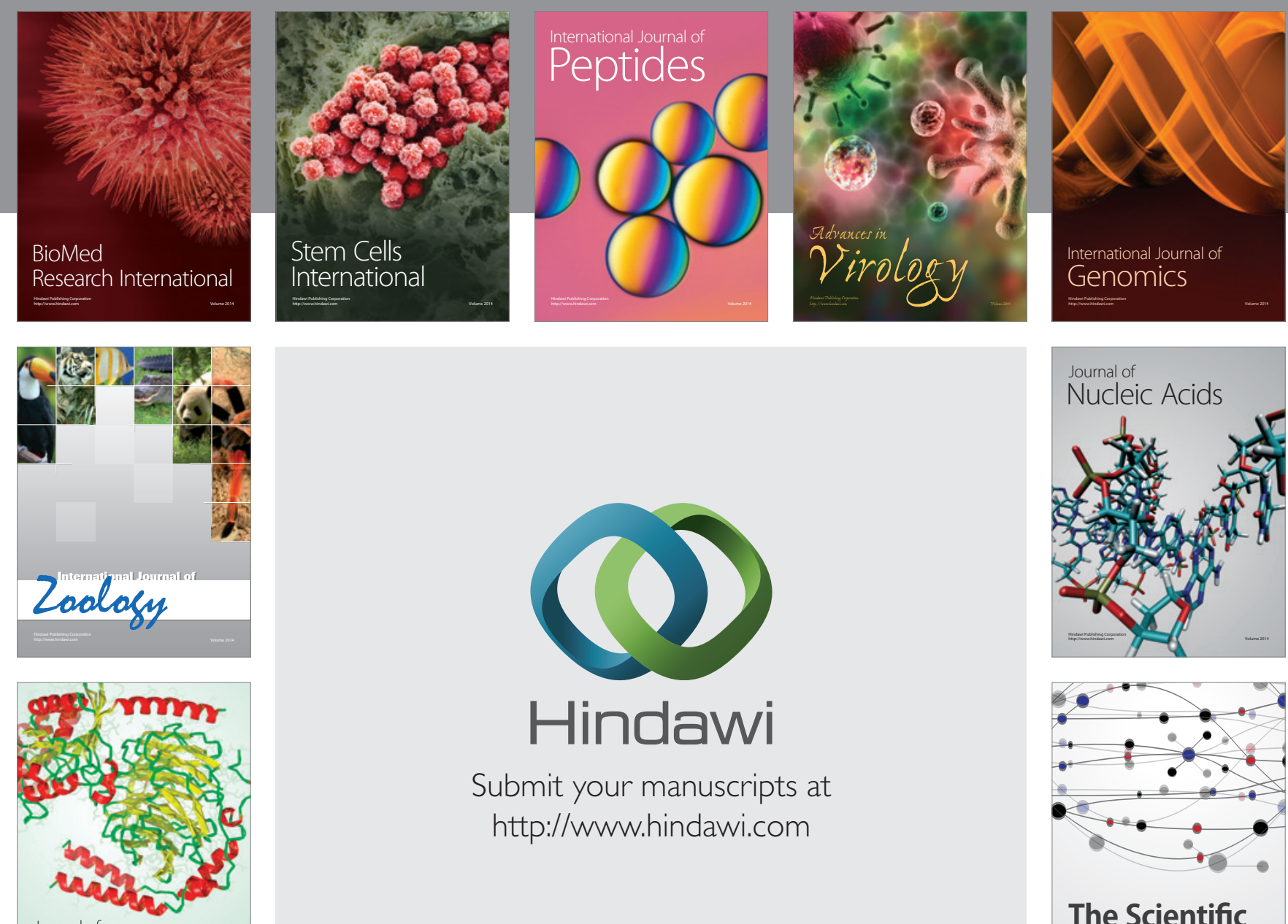

Submit your manuscripts at

http://www.hindawi.com

Journal of
Signal Transduction
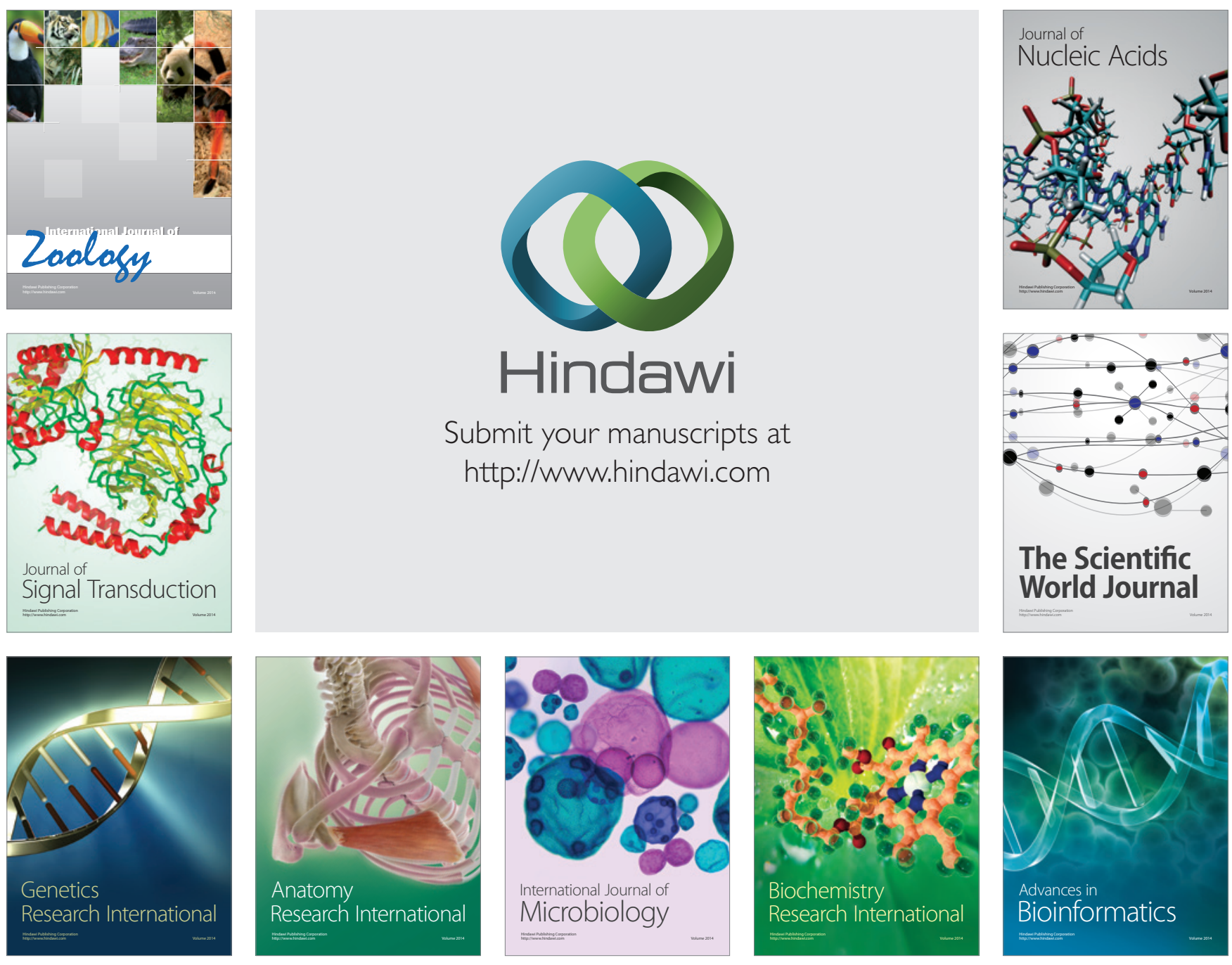

The Scientific World Journal
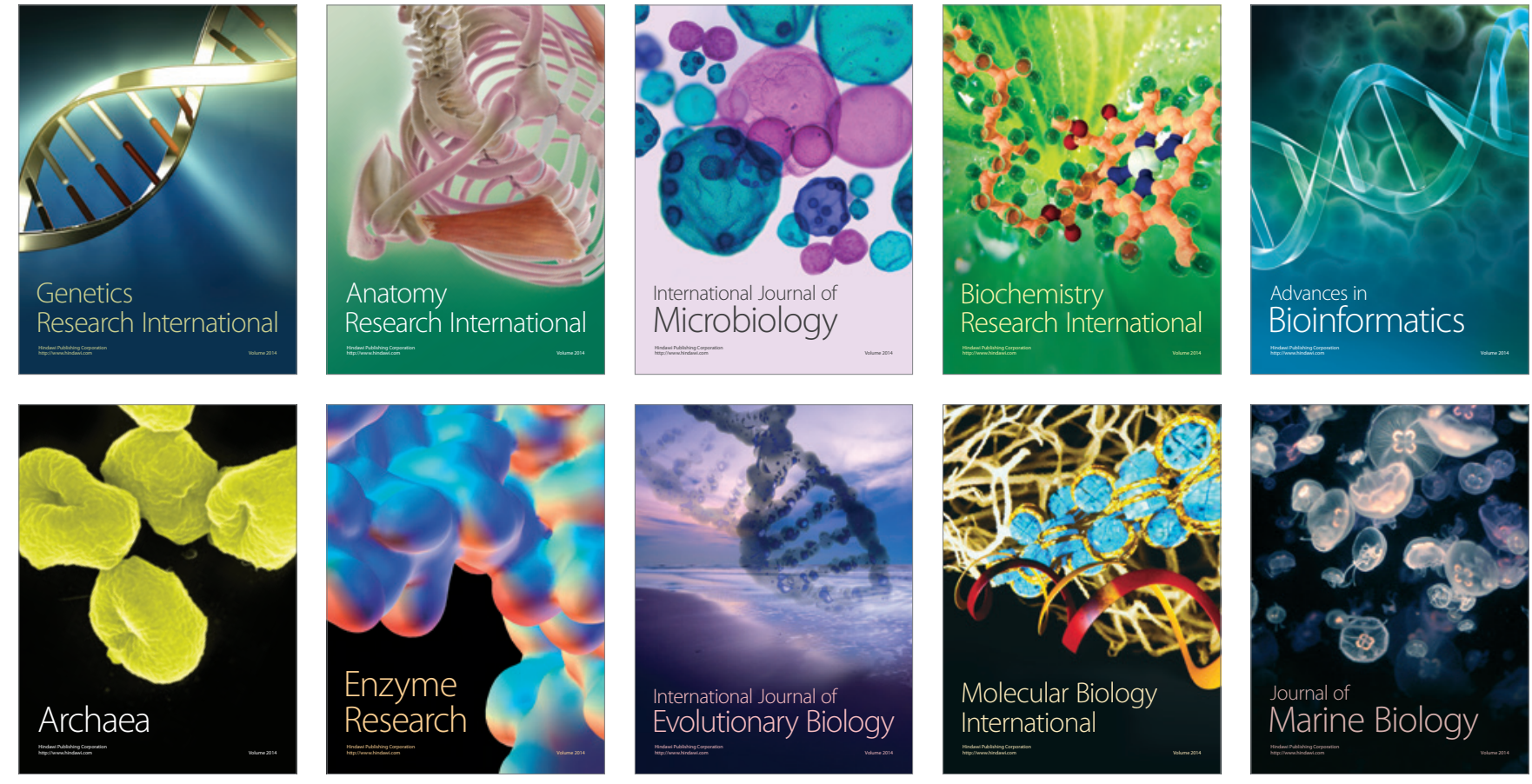